\title{
Religião, culto cristão e mídias como uma forma de religiosidade vivenciada: uma análise como tarefa da teologia prática ${ }^{1}$
}

\author{
Religion, Christian worship and media as a form of religiosity \\ experienced: an analysis of the task of practical theology
}

\begin{abstract}
Júlio Cézar Adam
Doutor em Teologia, professor na Faculdade EST, Faculdade Instituição Evangélica de Novo Hamburgo (IENH), Novo Hamburgo, RS - Brasil, e-mail: julioadam@est.edu.br; julio@ienh.com.br
\end{abstract}

\section{Resumo}

O artigo busca entender a relação entre religião, culto cristão e mídia. Parte-se da ideia de que na contemporaneidade vivemos um fenômeno amplo e complexo de transferência da religião e do religioso para o campo das mídias, tanto no que se refere às suas formas quanto aos seus conteúdos. A religião na e por meio das mídias constitui-se uma religiosidade vivenciada, diferente da religião institucional, mas, em vários aspectos, assume para as pessoas uma função cúltica e litúrgica. Entende-se que o estudo desta relação entre religião, culto e mídia é tarefa da teologia prática como um

1 Esse artigo foi originalmente apresentado sob o título "Deuses e liturgias nas mídias: a teologia prática como rastreamento da religião vivenciada”. II Congreso Internacional Ciencias, Tecnologías y Culturas, em Santiago do Chile, Chile, no ano de 2010. 
ADAM, J. C.

rastreamento e uma hermenêutica desta religião vivenciada, buscando, assim, elementos para se pensar o culto cristão hoje, no contexto latino americano.

Palavras-chave: Religião vivenciada. Culto cristão. Mídia.

\section{Abstract}

This article aims to understand the relation between religion, Christian worship and media. We start from the idea that we live a wide and complex phenomenon of religion and religious transference into the field of media in contemporaneity, both concerning media frames and contents. Religion, in and through media, consists of a religion experienced, different from the institutional religion, but which, in many aspects assumes a cultic and liturgical function for people. We understand that practical theology is in charge of studying this relation between religion, worship and media as tracing and hermeneutics of this religion experienced, this way searching for elements which can take us to reflect about the Christian worship within the Latin American context nowadays.

Keywords: Religion experienced. Christian worhip. Media.

\section{Introdução}

No limiar do século XXI, vivemos um fenomenal incremento do religioso (ALVES, 1988, p. 59-82). Ao contrário da secularização e o ocaso da religiosidade, vivemos um verdadeiro avivamento da religião, tanto da institucional, como da religiosidade que perpassa a cultura, por ser a religião parte integral da maneira humana de estar no mundo (BAUMAN, 2009, p. 75-108).

Uma das características desse fenômeno é a independência da religião de suas respectivas instituições. Vive-se uma transmigração e transgressão de fronteiras confessionais BOBSIN, 2002, p. 13, 30). Outra característica é a manifestação do religioso na esfera dita "profana", ou seja, fora da instituição religiosa, fora do culto, fora da própria esfera religiosa. Mais do que sincretismo, mais que transgressão de fronteiras, se dilui as próprias fronteiras entre sagrado e profano.

Rev. Pistis Prax., Teol. Pastor., Curitiba, v. 4, n. 1, p. 297-317, jan./jun. 2012 
Esta nuance do fenômeno é visível não apenas na América Latina, mas na sociedade contemporânea como um todo (GRÄB, 1995). Já na década de 1980, um estudo do antropólogo André Droogers apontava para uma matriz cultural religiosa brasileira que ia além da instituição religião, uma Religiosidade Mínima Brasileira (DROOGERS, 1987, p. 63). Na Alemanha, tal fenômeno é chamado de "gelebte Religion", ou seja, religião vivenciada (FAILING, 1998).

Essa religiosidade vivenciada no cotidiano está, pois, presente na literatura (MAGALHÃES, 2000), nos heróis das histórias em quadrinho (IRWIN, 2005), na moda e em tendências de comportamento (LIPOVETSKY, 2006), na música (CALVANI, 2010), no marketing (BOLTZ, 1995), nos sites da internet, no cinema (HERRMANN, 2000). Ou seja, a religião vivenciada está incrivelmente relacionada direta ou indiretamente, explícita ou implicitamente com as diferentes mídias (MELO, 2007). Suspeito que, assim como a liturgia e o culto veiculam a religião institucional, as mídias veiculam a religião fora da instituição.

Assim como a religião transpôs fronteiras e está presente fora da esfera explícitamente religioso-institucional, o mesmo acontece com o culto, à pregação e à liturgia, como formas de expressão da religião. As fronteiras do culto e sua liturgia, da pregação se diluíram entre o sagrado e o profano (STOLT, 1996) ${ }^{2}$. Televisão, cinema, revistas, internet expressam uma cultura religiosa imbricada na cultura popular, cotidiana.

As mídias veiculam mensagens carregadas de símbolos, proporcionam ritos e recontam mitos, que antes encontravam sua expressão na liturgia do culto dominical, por exemplo Sacralizam, assim, o tempo e o espaço, virtual e real, cuidam do corpo e do espírito, imagens e hipertextos. As mídias orientam e dão sentido para a existência das pessoas, como uma verdadeira liturgia sendo "celebrada" e ritualizada nas telas, páginas, imagens, iPods, mp3, 4, 5, etc, na vida cotidiana, na cultura pop. E mais ainda: na América Latina, essa nova liturgia dá espaço e vazão para elementos como

2 Na obra, STOLT, P.; GRÜNBERG, W.; SUHR, U. (Org.). Kulte, Kulturen, Gottesdienste: Öffentliche Inszenierung des Lebens. Göttingen: Vandenhoeck \& Ruprecht, 1996, encontramos vários artigos que demonstram a relação entre culto cristão na cultura dita profana, seja na arquitetura da cidade, no teatro, no cinema, no futebol, nos memoriais, nas festas e jogos, no marketing. 
o sincretismo, a religiosidade popular, herética, subversiva, malandra, engraçada, latina... Elementos banidos dos altares do culto oficial.

Entendendo a Teologia Prática não só como estudo da prática da Igreja, mas como mapeamento e interpretação da religião vivenciada ${ }^{3}$, me parece necessário e imprescindível um labor teológico latino-americano a partir dos deuses e liturgias presentes nas mídias e seus hipertextos "sagrados" e "profanos". Não estaria exatamente aí, no sem-fronteiras das mídias, uma Teologia autenticamente latino-americana?

Exatamente o mapeamento dessa religião midiática é o que pretendemos fazer neste estudo.

\section{Religiosidade vivida como uma bricolagem religiosa}

A chamada religiosidade vivida expressa ao mesmo tempo a amplitude e a fragmentação do fenômeno religioso, apontando para a nossa incapacidade de vislumbrar um enfoque linear e acabado do mesmo. Se existe algo de concreto frente ao fenômeno religião em suas interfaces com a mídia é, justamente, a in-concretude. A "metanarrativa” que nos restou é tão somente a fragmentação, ou seja, a fragmentação é a metanarrativa. Trazemos aqui, portanto, apenas aproximações conceituais e enfoques dessas interfaces.

De forma ampla, "definiria religião como os padrões transcendentes de ação e significado que contribuem para a relação com o sagrado e nela estão inseridos" (GANZEVOORT, 2009, p. 322). Religião é todo exercício humano de transcender e transpor os limites do tempo e do espaço, por meio da imaginação, na busca de sentido, de valor, de contato, de esperança, para que a vida seja suportável e viável. Na busca por detrás dos limites do tempo e do espaço o ser humano se encontra com o divino e lhe atribui formas e conteúdos. Religião é um produto humano. Como diria Alves:

a religião é a proclamação da prioridade axiológica do coração sobre os fatos brutos da realidade. Ela é a recusa, por parte do ser humano, de ser

\footnotetext{
3 Autores que trabalham nessa dimensão: Gert Otto, Wilhelm Gräb, Peter Cornehl e R. Ruard Ganzevoort.
} 
digerido e assimilado ao mundo que o cerca, em nome de uma visão, de uma paixão, de um amor (ALVES, 1988, p. 19).

Por isso, experiência religiosa é a grande marca da evolução humana, pois é nela que se descobre uma nova maneira de ser perante o mundo. O homem rejeita a natureza como estrutura final e passa a nortear sua vida pelo ideal e imaginário, passa a buscar o mundo, ao invés de simplesmente viver e sobreviver nele.

No mesmo rumo, a Teologia é uma tentativa de demarcar os contornos dessa busca humana. Ela é "uma expressão do projeto inconsciente e sem fim que é o coração do ser humano: a criação de um mundo com uma significação humana" (ALVES, 1988, p. 20). Como uma criação humana, provavelmente a Teologia nunca tenha sido uma grandeza singular, mas sempre plural. Hoje, isto tem ficado mais evidente do que nunca: as teologias escapam às dogmáticas, às instituições antes pretensamente suas detentoras, isto com todos os desdobramentos para a religião como tal e para a cultura. Como aponta Bobsin:

lastreadas pela globalização, as ideias religiosas ou as mercadorias circulam livremente pelo mundo, com a diferença de que estas não sofrem prejuízos, ao passo que aquelas assumem novas características. Pode-se tomar como exemplo a ideia da reencarnação. Arrancada do mundo do hinduísmo, Índia, é reinterpretada por Allan Kardec na Europa do século XIX e ressignificada pelo espiritismo brasileiro, sendo transfigurada pela New Age, perdendo, assim, não só o seu território e sua função social numa sociedade de castas ou hierárquica, mas também seus impulsos éticos (BOBSIN, 2002, p. 15).

Neste sentido, talvez a religião institucional tenha deixado há tempos de estruturar a sociedade e a cultura como um todo, mas o religioso continua como uma "entidade humana" às soltas, mais do que nunca criando elos de sentido entre as pessoas, criando e recriando o mundo. Um todo de fragmentos (RIBEIRO, 2009, p. 49).

Referindo-se à religião na pós-modernidade, Bauman afirma que: “o inefável é uma parte tão integral da maneira humana de estar no mundo quanto a rede linguística como que tentamos (em vão, e por acaso, embora não menos vigorosamente por essa razão) captá-lo" (BAUMAN, 1998, p. 295). 
É nesse sentido que se pode entender ao fenômeno a chamada religião vivivenciada (FAILING, 1998).

Onde pois encontramos hoje pistas desta religião? Com certeza não apenas na Igreja. Podemos encontrá-la nas colunas de aconselhamento nas revistas e nas ilustrações dos personagens fictícios dos comic strips, nas páginas de horóscopo, e no vasto mercado dos livros esotéricos. Podemos encontrá-la nas artes plásticas com suas chocantes e questionáveis obras, apontando para nossa imperceptível transcendência cotidiana. Podemos encontrá-la na terapêutica com sua oferta de vivência individual e meditações sincréticas. Podemos encontrá-la em facções políticas, que exigem relações de inclusão social e asseguram identidades pessoais. Podemos encontrá-la no consumo, através das propagandas com promessas religiosas. Podemos encontrá-la na indústria do turismo, no culto em torno à alimentação e aos exercícios físicos, que faz do paraíso uma promessa (GRÄB, 1995, p. 47, tradução nossa ${ }^{4}$ ).

No caso concreto do Brasil e América Latina, essa religião vivenciada, batizada por Droogers de RMB (Religiosidade Mínima Brasileira), assume as seguintes características:

trata-se de uma religiosidade que se manifesta publicamente em contextos seculares, que é veiculada pelos meios de comunicação de massa, mas também pela linguagem cotidiana. Ela faz parte da cultura brasileira. [...] a RMB não é o acervo ou mesmo matéria-prima da qual as religiões tiram seu repertório. [...] não tem clero, a não ser as pessoas que são os seus porta-vozes. Ela não tem escritura sagrada, a não ser os jornais e as revistas. Rituais são raros, mas talk shows na televisão podem acabar se tornando

\footnotetext{
4 "Wo aber finden wir heute dis Spuren dieser Religion? Eben nicht nur in der Kirche. Die Stiftung von Sinnzuschreiben, die Kontingenz aushalten helfen, hat in der Moderne westlicher Gesellschaften eine plurale Gestalt angenommen. Zu denken ist an die Lebensberatungskolumnen in Zeitschriften und Illustrierten, an die fiktiven Lebensbilder in Comic Strips, an die Horoslopblätter und einen breiten esoterischen Buchmarkt. Zu denken ist an die bildende Kunst mit ihren oft ebenso schckierenden wie rätselhaften Versinnlichungen dessen, was unserem eingeschliffenen Alltagsbewusstsein transzendent ist. Zu denken ist an die Therapieszene mit ihren Angeboten von Selbsterfahrung und synkretisch ausgelegter Meditation. Zu denken ist an politische Gruppierungen, die das Verlangen nach eindeutigen sozialen Zugehörigkeitsverhältnissen und personaler Identitätsvergewisserung für sich nützen. Zu denken ist an die Konsummentalität, die über die Werbung mit religiösen Versprechungen aufgeladen wird. Zu denken ist an die Tourismusindustrie, an Ernährungs- und Fitnesskulte, die das Paradies zu ihrem Angebot gemacht haben".
}

Rev. Pistis Prax., Teol. Pastor., Curitiba, v. 4, n. 1, p. 297-317, jan./jun. 2012 
cultos da RMB. Ela não conhece hinos, a menos que certas músicas de Roberto Carlos sejam vistas assim (DROOGERS, 1987, p. 63).

A seleção brasileira orando ajoelhada em círculo, no campo de futebol ${ }^{5}$, assim como o carnaval e as festas populares são exemplos da liturgia dessa religião vivenciada. Queremos, no entanto, nos deter, aqui, nos exemplos veiculados pela mídia.

\section{Mídias como expressão da religiosidade vivenciada}

Mídias são todo e qualquer suporte material que estabeleçam uma conexão entre dois pontos ou mais, com a finalidade de transmitir e/ou receber informações (KLEIN, 2006, p. 80-81). Pensando assim, a primeira e mais básica e, ao mesmo tempo, complexa mídia que temos conhecimento é o nosso próprio corpo. Mídias têm a ver com o exercício humano de extensão de si para transcender e transpor os limites físicos, do tempo e do espaço, a partir de ferramentas e da imaginação, tornando a comunicação mais eficaz e a sua vida melhor. Segundo McLuhan (1969), as tecnologias são como uma "pele" que vestimos para ser uma extensão do corpo. "Desde o utensílio mais rudimentar, como a pinça, por exemplo, até o mais sofisticado computador, estaríamos lidando com expansões de partes do nosso corpo, como os dedos (pinça) ou cérebro (computador)" (KLEIN, 2006, p. 81).

A partir do senso comum, hoje, as mídias têm a ver com os meios de comunicação de massa como livros, jornais, revistas, rádio, cinema, TV, telefones, internet e uma lista interminável de outros meios e recursos. Elas proporcionam informação, contato, projeção, extensão, visibilidade e reconhecimento, consumo, expressão de comportamentos, manutenção do status individual e de um grupo ou povo. Os avanços e impermanências nesse campo e todas as consequências positivas e negativas para o ser humano são virulentas e merecem um estudo a parte.

5 DIAS, H. Fifa Repreende Comemoração Religiosa da Seleção Brasileira. Disponível em: <http:// ieqindustrialcontagem.zip.net/arch2009-07-05_2009-07-11.html>. Acesso: 26 ago. 2010. 
Dois elementos vão chamar a atenção ao olhar as mídias na interface com a religião: o meio é a própria mensagem (MCLUHAN, 1969, p. 21) e esta mensagem-meio é religiosa explícita e implicitamente. Ou seja, a mídia como tal, como meio, como máquina, é em si uma mensagem e essa mensagem é religiosa. Trata-se de uma mídia religiosa. $\mathrm{O}$ outro elemento é a religião da mídia, que tem a ver mais especificamente com o seu conteúdo. Tal conteúdo pode ser explicitamente religioso, como por exemplo, a transmissão de missas e cultos pela TV, ou a confissão de pecados pela internet ${ }^{6}$, ou os cemitérios virtuais ${ }^{7}$ ou ainda o filme de Mel Gibson "A paixão de Cristo". A religião da mídia apresenta-se também de forma implícita, como, por exemplo, uma propaganda da Volkswagen mostrando que, se Moisés tivesse tido um carro gol, poderia ter cruzado o Mar Vermelho sem a necessidade de abri-lo. Esse aspecto será analisado no último ponto deste artigo.

Importante se dar conta de que tanto a mídia religiosa quanto a religião da mídia, com seus conteúdos explícitos e implícitos no imaginário popular, se mesclam. Um bom exemplo disto é quando o crente, em sua casa, durante um culto televisivo coloca um copo de água sobre o aparelho de TV para que água seja abençoada.

Tomemos o elemento da mídia religiosa: segundo McLuhan uma das principais características da mídia na atualidade é a sobreposição entre meio e mensagem. O meio é a própria mensagem. Ter um celular, por exemplo, ou poder usá-lo, comunica tanto - ou mais - que a comunicação entre duas pessoas por meio dele. Há certo encantamento com as máquinas, às quais devotamos tempo e dinheiro. Admiramos sua infalibilidade, exatidão, sua impecabilidade. "As modernas tecnologias fazem aparecer as coisas como se viesse do nada, uma característica ligada à magia e à religião" (KLEIN, 2006, p. 81). Há, portanto, nas máquinas midiáticas algo de religioso.

Pensemos uma definição sucinta para Deus: "Deus é um espírito onisciente e todo-poderoso que está dentro e fora de nós. Deus está sempre conosco porque é onipresente. É um mistério, e não poderemos nunca entendê-lo" (SCHWARTZ, 1985, p. 19). A mesma definição se aplicaria às mídias na atualidade. Diante da TV e do computador desenvolvemos

\footnotetext{
6 Confessar. Disponível em: <http://www.confessar.com.br/>. Acesso em: 3 mar. 2012.

7 Jardin Celestial. Disponível em: <http://www.jardincelestial.com/index.html>. Acesso em: 3 mar. 2011.
} 
verdadeiros ritos "religiosos". Em muitos lares brasileiros, por exemplo, a TV está na sala de estar ocupando o lugar onde antes ficava o altar da família ou a Bíblia. Ou, pessoas não conseguem iniciar o dia ou o trabalho sem o rito de ler o jornal e/ou acessar seus emails. Para muitos o celular é quase como um amuleto que dá segurança e protege.

Segundo Felinto, as tecnologias midiáticas são "tecnologias do imaginário". A partir delas - principalmente as mais recentes - é permitido ao ser humano a sensação de realizar fantasias humanas. Ao grau de consciência, seria a fantasia de expansão e de construção (de identidades, por exemplo) e de corpo as fantasias de desmaterialização e hibridação (FELINTO, 2005, p. 47). Portanto, no ritual diário diante das mídias, captamos não só informação, mas nos re-ligamos na imensa rede virtual em busca de orientação para a vida prática, afirmação de crenças e valores, expressão de sentimentos e emoções, nos projetando nas e por meio de imagens e sons. Vivenciamos uma realidade na e por meio da mídia. A partir das mídias, de forma especial as interativas conseguiram realizar o que antes era atributo somente de Deus: onipotência, onisciência e onipresença (THOMAS, 1998).

Tomemos ainda o elemento virtual e temos mais uma aproximação religiosa interessante. O virtual existe sem estar presente. "É virtual toda entidade 'desterritorializada', capaz de gerar diversas manifestações concretas em diferentes momentos e locais determinados, sem, contudo, estar ela mesma presa a um lugar ou tempo em particular" (LÉVY, 1999, p. 47). Na opinião do autor, o virtual não é oposto ao real, mas algo que existe em potência e não é ato. $O$ virtual é oposto ao atual. Os teólogos não precisam de muito esforço para encontrar referências bíblicas e teológicas que lembrem em muito algo de virtualidade, como, por exemplo a ideia de Reino de Deus, “já e ainda não” presente na realidade.

A religião, como acenamos anteriormente, é para o ser humano uma extensão transcendente, que rompe com os limites impostos pelo tempo e o espaço.

Na medida em que o ser humano se externaliza, ele constrói o mundo no qual se externalizar. No processo de externalização ele projeta as suas próprias significações sobre a realidade. Universos simbólicos, que proclamam que toda a realidade é humanamente significativa e que invocam o 
cosmo para testemunhar da validade da existência humana, constituem a extensão mais ampla desta projeção (BERGER, 1967, p. 104).

Essa extensão do transcendente tem encontrado na mídia consistência e viabilidade, mesmo quando no lugar de extensão se têm muito mais uma amputação ${ }^{8}$.

\section{Liturgia e o culto cristão como uma metanarrativa}

Busquemos ainda outra interface: o culto. Pelas ciências litúrgicas podemos dizer que, no culto cristão, circula a ação simbólico-representativa da igreja (darstellendes Hande) (SCHLEIERMACHER, 1850, p. 70), como comunicação pública da experiência cristã, mediada em forma e conteúdo pela tradição bíblica e pela tradição da igreja (CORNEHL, 1979, p. 186). Ou seja, o culto cristão - tanto o culto dominical comunitário, como a celebração dos sacramentos, as jornadas e passagens ${ }^{9}$ - foi e é a metanarrativa dos cristãos a partir de simbolização, da representação, da festa e do drama, por meio do rito. No culto, sintetizamos de forma ritual-simbólico-representativa toda a teologia cristã, toda a história da salvação, toda a experiência humana, comunitária e individual, com o Deus dos judeus e dos cristãos. O rito do culto possibilita que a comunidade e o indivíduo celebrantes experimentem e vivenciem, durante o tempo que o rito durar, em um determinado local, uma extensão com o transcendente ${ }^{10}$.

Visto pela antropologia, o culto é um jogo absorvente (GEERTZ, 1978, p. 278-321). Por meio do rito, a comunidade e a pessoa dizem para si quem são. Este é o sentido do culto: o rito litúrgico expressa não

\footnotetext{
8 McLuhan já fazia referência sobre essa amputação em seus estudos. Alberto Klein traz um excelente estudo, mostrando como as mídias têm limitado o ser humano e o corpo.

9 Por jornadas e passagens entendem-se todos os ritos de iniciação, de passagem, de dedicação, os chamados ofícios casuais, sacramentos ou sacramentais, como batismo, confirmação/crisma, reconciliação/penitência, matrimônio, funeral, unção dos enfermos, eucaristia, ordenação.

100 teólogo reformado Jean-Jacques von Allmen dirá que o culto é a recapitulação da história da salvação. Ele é o resumo e a confirmação, por meio do Espírito Santo, de toda esta história salvífica. 0 culto é epifania, revelação da Igreja para si e para o mundo, por meio da promessa e do juízo, sendo o mundo profundamente afetado pelo culto cristão.
}

Rev. Pistis Prax., Teol. Pastor., Curitiba, v. 4, n. 1, p. 297-317, jan./jun. 2012 
apenas sentimentos e desejos, mas reafirma, corrige, restabelece princípios, regras, recria relações diante de si, dos outros, do mundo e de Deus. O rito proporciona aos seus participantes orientação, expressão, afirmação e integração (CORNEHL, 1979, p. 178-195).

Culto é o espelho das pessoas que lhe dão forma e conteúdo. Ou seja, as pessoas fazem o culto e, ao mesmo tempo, elas são constituídas pelo culto. Assim como a Teologia nasce do culto e é sempre de novo refeita a partir e no culto. Culto é extensão das pessoas que o celebram, sendo o meio e a mensagem uma e a mesma coisa. Sendo assim, o culto por meio da liturgia é uma forma de mídia (GRÄB, 2002, p. 157). Como rito, essa dimensão midiática é sempre muito concreta, corporal, ligada aos sentidos, a partir do contato real, físico entre as pessoas, mas também utilizando-se de meios extracorporais, da virtualização do corpo (KLEIN, 2006, p. 86).

O culto cristão foi a principal mídia da Igreja, o meio e a mensagem, por séculos. Extensão do humano a uma dimensão transcendente por meio dos símbolos, imagens, música, textos, silêncios, movimentos, gestos. Uma mídia simbólico-representativa intensa e precisa. Uma metanarrativa em forma de jogo absorvente que, ao mesmo tempo em que dava forma às pessoas e ao mundo, se reconstituía a si própria.

Nesta perspectiva, o fato de hoje as mídias assumirem o papel simbólico-representativo do culto, foi um pequeno passo. Em seu livro Die Welt ist voll von Liturgie (CORNEHL, 2005), sinaliza que as tantas expressões da cultura cotidiana estão carregadas de símbolos, ritos e mitos que antes encontravam sua expressão na liturgia do culto dominical: o grito por amparo do Kyrie eleison, a explosão de louvor do Glória in excelsis e do Sanctus, o lidar com a culpa da penitência, a festa e o sonho utópico da comunhão eucarística, os momentos de passagem dos ofícios, sejam nas situações de crise, sejam na valorização das identidades pessoais (CORNEHL, 1975, p. 388-401), a sacralização do tempo e do espaço, o cuidado com o corpo e o espírito, as palavras que orientam e dão sentido para a existência, todos esses elementos litúrgicos estão sendo "celebrados" na cultura e na mídia, fora do culto e dos ritos institucionais das igrejas (GRIMES, 1993, p. 23-37) ${ }^{11}$. A maior

${ }^{11}$ Esse fenômeno se difere dos novos rituais, os chamados Emergings rituals como encontramos em: GRIMES, R. L. Emerging ritual. In: GRIMES, R. L. Reading, writing, and ritualizing. Ritual in fictive, liturgical and public 
diferença entre o culto midiático e culto rito é que neste as pessoas estão implicadas praticamente, como atores, enquanto naquele estão implicadas, na maioria dos casos, tão somente emocionalmente (LÉVY, 1999, p. 116).

Outro desdobramento da relação culto-mídia é o fato de que o culto cristão e seus ritos têm assumido mais e mais elementos e recursos da própria mídia (KLEIN, 2006, p. 141). Cada vez mais os cultos e os ofícios casuais nas igrejas têm assumido a forma de estúdio de televisão, com música de fundo, jogo de luzes, performances midíaticas, como, por exemplo, os "casamentos cinematográficos” ou os cultos que mais parecem um talk show.

\section{Vivenciando um pouco desta religiosidade e suas "liturgias" midiáticas}

Cada uma destas interfaces anteriormente apresentadas traz aproximações que levam a perceber o quanto religião está relacionada com teologia, o quanto a Teologia está relacionada com liturgia, o quanto estas estão relacionadas com as mídias - meio e mensagem - de forma explícita e implícita, e o quanto tudo está relacionado com os seres humanos. Todas, a sua maneira, veiculam concreta ou virtualmente a existência humana em sua busca por sentido e transcendência. As mídias também veiculam formas de sentido, horizontes simbólicos, dentro das quais nós interpretamos nossas experiências cotidianas. Com ajuda das mídias encontramos uma linguagem para nossos desejos, esperanças e medos (GRÄB, 2002, p. 135). Olhemos, pois, três exemplos desta "liturgia" vivenciada na mídia, tomando-as como exemplos latino-americanos.

\section{Propaganda Shopping Center Barra Sul}

Trata-se de um a propaganda de um shopping na cidade do Rio de Janeiro ${ }^{12}$. A propaganda se desenrola a partir da conversa de Deus com Pedro, planejando a criação da Cidade Maravilhosa.

places. Washington, D.C.: The Pastoral Press, 1993. p. 23-37.

12 Deus criando o Rio de Janeiro (Comercial Shopping Rio Sul). Disponível em: <http://www.youtube.com/ watch?v-7eUuqLNiu1Q>. Acesso em: 23 jun. 2010. 
Algo típico nas propagandas de hoje é não falar do produto em si, mas dos valores agregados à marca e ao produto. Apela-se para os valores humanos, os sentimentos e a emoção de tal forma que a própria propaganda já é uma vivência, uma antecipação virtual na mídia do que se experimentará na realidade, no ato. A ideia não é adquirir o produto, mas ser alguém adquirido pela marca, fazer parte, inscrever-se no mundo a partir da marca e do produto (LIPOVETSKY, 2007, p. 46).

No caso desta propaganda, há uma forte referência à cidade do Rio de Janeiro, sua gente, suas belezas. Um lugar que Deus criou com o propósito de ser belo, bom e aprazível para se viver. Tão perfeito, que Pedro gostaria de ser o padroeiro. Trabalha com elementos do catolicismo popular - conversa entre Deus Criador e São Pedro, faz referência ao padroeiro São Sebastião, ao Cristo, filho de Deus, e elementos cotidianos e seculares. Deus cria, por exemplo, o happy hour no barzinho, o surf, o futebol, o samba e praia no domingo, para compensar o "ralar" semanal, pôr do sol cinematográfico e a estátua do "garoto", filho de Deus (o Cristo é criação divina!). Fala, música e imagens se complementam. Numa criação tão perfeita e exclusiva como o Rio, só faltava mesmo o Shopping Barra Sul para ser perfeito; templo de adoração e curtição da vida e do Rio (dentro do Shopping?). Antes de anunciar quem está por detrás da propaganda, o shopping, é dita a frase: "O carioca já nasce abençoado e quando Deus abençoa é pra sempre". O shopping é mais uma bênção para o Rio. Temos aqui um Deus imanente, não só brasileiro, mas carioca, envolvido sentimentalmente ao extremo com um lugar e sua gente e envolvido com o shopping e tudo que ele representa, apresentado por meio de perfeito jogo de imagens, sons, ideias imanentes e transcendentes, cotidianas e tradicionais, com um desfecho marcante e engraçado, envolvendo o ouvinte emocionalmente.

\section{Comunidade do Orkut: eu acredito e confio em Deus - EACD}

Milhares de comunidades, sites, blogs surgem a cada segundo nos mais diferentes espaços virtuais, com interesse religioso. A comunidade no Orkut "Eu acredito e confio em Deus - EACD"13, criada por Annaah

13 LAUX, A. Disponível em: <http://www.orkut.com.br/Main\#Community?cmm=342550>. Acesso em: 28 ago. 2010. 
Laux, chama a atenção pela descrição da comunidade e o número de membros. Conforme descrição, a comunidade tem como objetivo propagar o amor de Deus para com todos, contribuindo para que se edifique a fé das pessoas, auxiliando quem estiver passando por dificuldades e aproximando pessoas que buscam a comunhão com Deus.

Os critérios da comunidade deixam claro o quanto se tem uma visão "transversal" diante da religião:

visto que nesta comunidade acontecem frequentemente debates/discussões envolvendo assuntos religiosos algumas vezes ocasionando desrespeito e nos piores casos, até mesmo brigas entre os membros, informamos que a paz e o respeito têm privilégio nesta comunidade. Assim, os membros que desrespeitarem as crenças de outros membros ou os próprios membros, e também aqueles que demonstrarem não estar bem intencionados e que desejam apenas semear a discórdia poderão ser advertidos ou até mesmo banidos para sempre da EACD. Caso um membro desrespeite outro dentro de um determinado tópico poderá ter todas as suas postagens deletadas dentro do mesmo ${ }^{14}$.

Atualmente a comunidade reúne 6.287.197 membros. Para essa comunidade, religião é assunto de extrema importância, não por sua dogmática ou suas tradições e ritos, mas por ser algo que se acredita, se confia para viver. Fé em Deus é algo funcional. Não quer ser uma comunidade para debater diferenças teológicas, mas fortalecer a confiança no "Deus de todos os nomes", como canta Milton Nascimento. A imparcialidade religiosa é um critério. Deus não é algo para se entender, mas para se viver. O rito litúrgico, aqui, consiste em aderir à comunidade e trocar materiais e informações que ajude os membros a acreditarem e confiarem em Deus.

\footnotetext{
14 LAUX, A. Disponível em: <http://www.orkut.com.br/Main\#CommMsgs.aspx?cmm=342550\&tid=53396442 86271487018>. Acesso em: 30 out. 2011.
}

Rev. Pistis Prax., Teol. Pastor., Curitiba, v. 4, n. 1, p. 297-317, jan./jun. 2012 


\section{Casamento na novela Viver a vida}

A trama da novela Viver a vida ${ }^{15}$ girava em torno à condição da modelo Luciana (Alinne Moraes), que, após um acidente, fica tetraplégica. A superação é o tema central de toda a novela. Luciana é o exemplo mais espetacular de superação. Submetida à cadeira de rodas, ela é transformada e transforma seu entorno. Seu casamento com o médico Miguel (Mateus Solano), já nos últimos capítulos da novela, é mais um passo de sua superação e transformação ${ }^{16}$.

Podemos dizer que todo o enredo de superação da novela tem enfoques claramente religiosos. $\mathrm{O}$ que chama a atenção na cena do casamento é o caráter explícito do religioso. Poucas vezes uma novela trouxe tanta precisão litúrgica, como neste caso. A liturgia do matrimônio está praticamente na íntegra. Toda a cena dura mais de 10 minutos. No texto, principalmente na fala do padre, o enredo foge aos padrões formais e conservadores: o padre fala em sua pregação de superação e usa o texto da carta aos Gálatas $(G 13,28)$. A partir do texto, diz sentir-se abençoado por estar diante de pessoas que conhecem verdadeiramente o sentido das palavras obstáculos, superação e preconceito. Reconciliação, e não o discurso moralizante é aqui o mote para a superação. As palavras do compromisso, da troca das alianças e da oração do Pai Nosso são trazidos na íntegra. Para cada parte do texto litúrgico, não só os noivos, mas demais personagens e as falas paralelas são focadas, fazendo uma clara relação destas com o que está sendo dito no texto. Músicas de fundo embalam a cena, criando um clima de muita emoção. O telespectador sente-se parte da cena.

Seguindo o rastro do sagrado, podemos dizer que estes três exemplos trazem elementos teológicos e religiosos, tanto no conteúdo, quanto na forma. Vejamos algumas características:

a) Uma liturgia estética que fala à emoção e aos sentimentos

15 Telenovela de Manoel Carlos, sob a direção de Jayme Monjardim, Fabrício Mamberti, exibida pela Rede Globo, no horário das 20 horas, entre os anos de 2009 e 2010.

16 Viver a vida - Luciana e Miguel. Disponível em: <http://www.youtube.com/watch?v=SH-AWfa2wME\&p=D35 A718FCC82A75D\&playnext=1\&index=26>. Acesso em: 23 ago. 2010. 
A religião vivenciada na mídia é profundamente estética. Mais do que contemplação e doutrina, ela proporciona uma vivência. Sendo a TV e o computador extensões do nosso corpo, quando os acessamos ou a eles assistimos, é como se fizéssemos parte ${ }^{17}$. A vivência estética se dá muito mais pelas emoções e os sentimentos do que pela razão.

A experiência estética sempre esteve muito próxima da experiência religiosa, pois parte da imaginação e extrapola a linguagem. Diante do "belo", experimentamos certos sentimentos que não se encontram nem em quem aprecia e nem no que é apreciado em si: encontra-se, sim, na experiência de dissolução da dicotomia entre aquele que contempla e aquilo que é contemplado. Esta seria a revelação do Espírito: síntese que recupera a unidade paradisíaca perdida e buscada pelo ser humano (ALVES, 1988, p. 118-120).

A partir da estética vivenciada e da experiência, a religião midiática vai ao encontro da tendência pós-moderna de trazer para o presente uma experiência transcendente, uma experiência máxima, um "viver a fundo" sensações nunca experimentadas antes e mais intensas do que qualquer antes provada (BAUMAN, 1998, p. 224). O agora é que importa e é onde encontramos Deus. Deus está envolvido na nossa experiência emocional. Por meio desta vivência o experimentamos.

b) Uma liturgia bricolada e universal

Nos três exemplos, temos uma clara mistura de elementos religiosos, seculares, culturais e pessoais. É uma liturgia "colcha de retalhos", uma verdadeira bricolagem, em que tudo pode fazer parte, formando um todo, o espectador ou internauta fazem parte, seja assistindo, vivenciando ou interagindo.

Lévy fala que uma das características da cibercultura é o universal sem totalidade. Abrange todo o universo, sem fechar-se um sentido.

Quanto mais o ciberespaço se amplia, mais ele se torna 'universal' e menos o mundo informacional se torna totalizável. O universal da cibercultura não possui nem centro nem linha diretriz. É vazio, sem conteúdo

\footnotetext{
17 Interessante que quando nos referimos ao que a TV está transmitindo, falamos muito "estou assistindo, estou vendo alto" do que "a TV está transmitindo". 0 mesmo se dá em relação ao computador. Quem é conectado à rede é a máquina, mas nos referimos a nós: "estou conectado, estou navegando, estou acessando".
}

Rev. Pistis Prax., Teol. Pastor., Curitiba, v. 4, n. 1, p. 297-317, jan./jun. 2012 
particular. Ou antes, ela os aceita todos, pois se contenta em colocar em contato um ponto qualquer com qualquer outro, seja qual for a carga semântica das entidades relacionadas (LÉVY, 1999, p. 111).

Deus está claramente presente, mas Ele não é o centro. O centro, se há um centro, são as pessoas e suas vidas, sua felicidade, a paz na convivência, o prazer e a satisfação. Por isso, a compreensão de Deus nos três casos é extremamente aberta, universal e humana. Não se abandona elementos da Bíblia e da tradição, mas estes elementos são livremente adaptados a uma funcionalidade humana.

c) Uma liturgia vivenciada por meio da imaginação

Participamos desta liturgia não só com os olhos e os ouvidos, mas com nosso ser inteiro, com a imaginação. Mais do que apenas assistir, a religião aqui é vivenciada. Sou convocado a interagir, seja com minha adesão ou minha opinião, no caso do Orkut, ou envolvendo-me por meio da imaginação, me espelhando nas personagens, fazendo relação com minha vida, rompendo com a realidade limitada.

Religião é imaginação e, inversamente, a imaginação tem sempre uma função religiosa para o ser humano. [...] A imaginação só se torna compreensível se percebemos que ela se constrói a partir de uma suspeita de que é provável que os limites do possível sejam muito mais extensos que os limites do real. A imaginação é a consciência de uma ausência, a saudade daquilo que ainda não é, a declaração de amor pelas coisas que ainda não nasceram (ALVES, 1988, p. 24, 46).

Por detrás de cada um dos exemplos, há a imaginação de uma outra realidade, melhor do que a realidade tal qual experimentamos.

\section{Conclusão: a tarefa da teologia prática}

O que fazer com esta "liturgia" das mídias? Por muito tempo, a Teologia e a Igreja tiveram diante das mídias uma postura crítica, negativa e, até, demonizante. A mídia seria a culpada de todo o mal do mundo e da 
deserção dos membros da vida comunitária. Mais recentemente, a Igreja buscou aproximar-se das mídias, utilizando-se de seus meios para transmitir mensagens religiosas. Essa aproximação, com raríssimas exceções, é mal-feita, de baixa qualidade, usando as mídias exatamente assim como tendenciosa e manipuladora, antes criticada. Até hoje as mídias continuam sendo para a Igreja e a Teologia algo não entendido e assimilado.

Segundo Gräb é, sim, tarefa da teologia prática pensar e zelar pela vida da Igreja, mas também entender e interpretar a religião que está fora da vida da Igreja, na cultura pessoal e social do nosso tempo (GRÄB, 2002, p. 39). Ganzevoort irá falar da teologia prática como tarefa hermenêutica, um rastrear do sagrado, dando-se conta da religião vivenciada e interpretando-a para dentro da própria Teologia e Igreja

como uma hermenêutica da religião vivenciada, acredito que a Teologia Prática pode desempenhar um papel importante em estabelecer conexões: entre a práxis religiosa e suas tradições e fontes, entre formas de práxis religiosa diferentes e conflitantes entre si, entre relatos teológicos e sociocientíficos da práxis religiosa, entre igreja e a sociedade, e assim por diante (GANZEVOORT, 2010, p. 340).

Seguindo o rastro do sagrado, a partir dos nossos três exemplos, nos damos conta de que a religião vivenciada a partir das mídias se diferencia muito, tanto como meio quanto como conteúdo, da tradição e da liturgia da Igreja. Podemos, no entanto, também dizer que, diante do que vemos e ouvimos, é impossível não levar em consideração aspectos como estética, emoção e sentimentos, visão abrangente e universal de Deus e do Sagrado e, acima de tudo, a funcionalidade e utilidade da religião dentro da vida das pessoas, hoje.

Se tais elementos são latino-americanos, não sabemos. Mas, se pensarmos no princípio encarnacional da teologia cristã, teríamos nestes e outros aspectos das mídias, muito para refletir no nosso contexto. Se esses aspectos são teologicamente adequados, não sabemos - muitos dirão que não são -, mas, o de que precisamos nos dar conta é que eles têm movido milhões de pessoas em sua religiosa relação com a vida e com o transcendente, em uma religião que é, sim, antes e acima de tudo vivenciada. 
Por isto, a religião continuará, até o fim, como expressão de amor e como expressão de medo. O ser humano viverá, para sempre, num mundo de deuses e demônios, símbolos de suas aspirações e temores - ainda que estes mesmos símbolos se envergonhem de suas próprias origens e, como travestis, se vistam com roupagens seculares. Como [...] observou Durkheim, "há algo de eterno na religião que está destinado a sobreviver a todos os símbolos particulares com que o pensamento religioso sucessivamente se envolveu" (ALVES, 1988, p. 58).

\section{Referências}

ALVES, R. $O$ enigma da religião. 4. ed. Campinas: Papirus, 1988.

BAUMAN, Z. 0 mal-estar da pós-modernidade. Rio de Janeiro: J. Zahar, 1998. BECKS, H. Der Gottesdienst in der Erlebnisgesellschaft. Waltrop: Spenner, 1999. BERGER, P.; LUCKMANN, T. The social construction of reality. New York: Doubleday \& Co., 1967.

BOBSIN, O. Correntes religiosas e globalização. São Leopoldo: CEBI; PPL; IEPG, 2002.

BOLTZ, N.; BOSSHART, D. Kult Marketing: die Neuen Götter des Marktes. Düsseldorf: Econ, 1995.

CALVANI, C. E. Momentos de beleza: teologia e MPB a partir de Tillich. Portal de Publicações Científicas, n. 8. Disponível em: <http://www.metodista.br/ $\mathrm{ppc/correlatio/correlatio08/momentos-de-beleza-2013-teologia-e-mpb-a-}$ partir-de-tillich>. Acesso: 21 mar. 2010.

CORNEHL, P. Frömmigkeit, Alltagswelt, Lebenszyklus: Propädeutische Notizen. Wissenschaft und Praxis in Kirche und Gesellschaft, v. 64, p. 388-401, 1975.

CORNEHL, P. Theorie des Gottesdienst. Theologie Quartalsschrift, n. 159, 1979.

CORNEHL, P. Die Welt ist voll von Liturgie: Studien zu Einer Integrativen Gottesdienstpraxis. Stuttgart: Kohlhammer, 2005.

DROOGERS, A. Religiosidade mínima brasileira. Religião e Sociedade, v. 14, n. 2, p. 62-86, 1987. 
FAILING, W.-E.; HEIMBROCK, H.-G. Gelebte religion Wahrnehmen: Lebenswelt, Alltagskultur, Religionspraxis. Stuttgart: Kohlhammer, 1998.

FELINTO, E. A religião das máquinas: ensaio sobre o imaginário da cibercultura. Porto Alegre: Sulina, 2005.

GANZEVOORT, R. R. Encruzilhadas do caminho no rastro do sagrado. Estudos Teológicos, São Leopoldo, v. 49, n. 2, p. 317-343, 2009.

GEERTZ, C. A interpretação das culturas. Rio de Janeiro: J. Zahar, 1978.

GRÄB, W. Sinn fürs Unendliche: Religion in der Mediengesellschaft. Gütersloh: Chr. Kaiser/Gütersloher Verlg., 2002.

GRÄB, W . Auf den Spuren der Religion. Zeitschrift für Evangelische Ethik, n. 39, p. 43-56, 1995.

GRÄB, W. Lebensgeschichten, Lebensentwürfe, Sinndeutungen: eine Praktische Theologie Gelebter Religion. 2. Aufl. Gütersloh: Gütersloher Verlag, 2000.

GRIMES, R. L. Reading, writing, and ritualizing:ritual in fictive, liturgical and public places. Washington, D.C.: The Pastoral Press, 1993.

HERRMANN, J. Sinnmaschine Kino: Sinndeutungen und Religion im Populären Film. Gütersloh: Kaiser, 2000.

IRWIN, W. (Coord.). Super-heróis e a filosofia: verdade, justiça e o caminho socrático. São Paulo: Madras, 2005.

KIRSNER, I. Film, Fragment, Fraktal: eine Kleine Kino-Apokalypse. In: STOLT, P.; GRÜNBERG, W.; SUHR, U. (Hrsg.). Kulte, Kulturen, Gottesdienste: Öffentliche Inszenierung des Lebens. Göttingen: Vandenhoeck \& Ruprecht, 1996. p. 50-62.

KLEIN, A. Imagens de culto e imagens da mídia: interferências midiáticas no cenário religioso. Porto Alegre: Sulina, 2006.

LÉVY, P. Cibercultura. São Paulo: Editora 34, 1999.

LIPOVETSKY, G. A felicidade paradoxal: ensaio sobre a sociedade de hiperconsumo. São Paulo: Companhia das Letras, 2006.

LIPOVETSKY, G. A felicidade paradoxal: ensaio sobre a sociedade de hiperconsumo. São Paulo: Companhia das Letras, 2007. 
MAGALHÃES, A. Deus no espelho das palavras. São Paulo: Paulinas, 2000.

MCLUHAN, M. Os meios de comunicação como extensões do homem. 5. ed. São Paulo: Cultrix, 1969.

MELO, J. M. de; GOBBI, M. C.; ENDO, A. C. B. (Org.). Mídia e religião na sociedade do espetáculo. São Bernardo do Campo: UMESP, 2007.

REBLIN, I. A. A teologia do cotidiano. In: BOBSIN, O. et al. (Org.). Uma religião chamada Brasil: estudos sobre religião e contexto brasileiro. São Leopoldo: Faculdades EST; Oikos, 2008.

REBLIN, I. A. Para o alto e avante!: mito, religiosidade e necessidade de transcendência na construção dos super-heróis. Protestantismo em Revista, v. 4, n. 2, maio/ago. 2005. Disponível em: <http://www3.est.edu.br/nepp/revista/007/07iuri. htm>. Acesso em: 22 dez. 2008.

RIBEIRO, J. C. Religiosidade jovem: pesquisa entre universitários. São Paulo: Loyola; Olho d’Água, 2009.

SCHLEIERMACHER, F. Die Praktische Theologie nach den Grundsäzen der Evangelischen Kirche. Berlin: O. Reimer, 1850.

SCHULTZ, A. Estrutura teológica do imaginário religioso brasileiro. In: BOBSIN, O. et al. (Org.). Uma religião chamada Brasil: estudos sobre religião e contexto brasileiro. São Leopoldo: Faculades EST; Oikos, 2008. p. 27-60.

SCHWARTZ, T. Mídia: o segundo Deus. São Paulo: Summus, 1985.

STOLT, P.; GRÜNBERG, W.; SUHR, U. (Org.). Kulte, Kulturen, Gottesdienste: Öffentliche Inszenierung des Lebens. Göttingen: Vandenhoeck \& Ruprecht, 1996.

THOMAS, G. Medien, Ritual, Religion: zur Religiösen Funktion des Fernsehens. Frankfurt: Suhrkamp, 1998.

Recebido: 16/10/2011

Received: 10/16/2011

Aprovado: 04/12/2011

Approved: 12/04/2011 